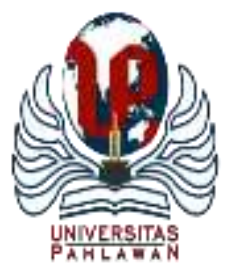

Edukatif : Jurnal Ilmu Pendidikan Volume 3 Nomor 5 Tahun 2021 Halm 3256 - 3262

EDUKATIF: JURNAL ILMU PENDIDIKAN

Research \& Learning in Education

https://edukatif.org/index.php/edukatif/index

\title{
Keefektifan Model Pembelajaran Think Talk Write pada Keterampilan Menulis Teks Negosiasi Siswa SMK
}

\author{
Hana Awu Utami ${ }^{1 凶}$, Dian Hartati ${ }^{2}$, Roni Nugraha Syafroni ${ }^{3}$ \\ Universitas Singaperbangsa Karawang,Indonesia ${ }^{1,2,3}$ \\ E-mail : $1710631080070 @$ student.unsika.ac.id $^{1}$, dian.hartati@fkip.unsika.ac.id ${ }^{2}$, \\ roni.nugraha@fkip.unsika.ac.id ${ }^{3}$
}

\begin{abstract}
Abstrak
Penelitian ini dilatarbelakangi oleh rendahnya kemampuan menulis teks negosiasi siswa kelas $\mathrm{X}$ di SMK Informatika Amanah Bangsa. Tujuan penelitian ini adalah untuk mengetahui keefektifan penerapan model pembelajaran Think Talk Write dalam pembelajaran menulis teks negosiasi di SMK Informatika Amanah Bangsa. Penelitian ini merupakan penelitian kuantitatif dengan metode eksperimen. Sampel penelitian sebanyak 50 siswa dan dibagi menjadi kelas eksperimen dan kelas kontrol. Berdasarkan hasil analisis, skor $\mathrm{N}-$ Gain yang diperoleh kelas eksperimen sebesar 0,530 dengan kategori tinggi. Sedangkan skor N-Gain pada kelas kontrol sebesar 0,054 dengan kategori sedang. Maka, model pembelajaran Think Talk Write efektif jika diterapkan dalam pembelajaran menulis teks negosiasi di SMK Informatika Amanah Bangsa.
\end{abstract}

Kata Kunci: ekektifitas, Think Talk Write, teks negosiasi.

Abstract

This research is motivated by the low ability to write negotiating texts for class X students at SMK Informatika Amanah Bangsa. The purpose of this study was to determine the effectiveness of the application of the Think Talk Write learning model in learning to write negotiating texts at SMK Informatika Amanah Bangsa. This research is a quantitative research with experimental method. The research sample was 50 students and divided into experimental class and control class. Based on the results of the analysis, the N-Gain score obtained by the experimental class was 0.530 in the high category. Meanwhile, the N-Gain score in the control class was 0.054 in the medium category. So, the Think Talk Write learning model is effective if it is applied in learning to write negotiating texts at SMK Informatika Amanah Bangsa.

Keywords: effectiveness, Think Talk Write, negotiating text.

Copyright (c) 2021 Hana Awu Putri Utami, Dian Hartati, Roni Nugraha Syafroni

$\triangle$ Corresponding author

Email : 1710631080070@student.unsika.ac.id

DOI : https://doi.org/10.31004/edukatif.v3i5.1256

ISSN 2656-8063 (Media Cetak)

ISSN 2656-8071 (Media Online) 
3257 Keefektifan Model Pembelajaran Think Talk Write pada Keterampilan Menulis Teks Negosiasi Siswa SMKHana Awu Putri Utami, Dian Hartati, Roni Nugraha Syafroni

DOI: https://doi.org/10.31004/edukatif.v3i5.1256

\section{PENDAHULUAN}

Kehidupan manusia sebagai makhluk sosial sering kali menemukan perbedaan antara satu individu dengan individu lain. Perbedaan yang ditemui yaitu perbedaan pandangan, pikiran, perbuatan, tingkah laku, dan lain-lain. Perbedaan tersebut merupakan hal wajar dalam sebuah lingkungan. Maka dari itu, manusia dalam kehidupannya tidak akan lepas dari bernegosiasi karena tujuan negosiasi adalah mengatasi atau menyesuaikan perbedaan, memperoleh sesuatu dari pihak lain, mencapai kesepakatan, dapat diterima oleh kedua belah pihak untuk melakukan transaksi, menyelesaikan sengketa atau perselisihan pendapat dan tidak dapat dipaksakan. Dengan bernegosiasi, maka suatu perbedaan tersebut dapat menjadi kesepakatan bersama.

Kondisi bernegosiasi remaja dapat ditemui pada berbagai kegiatan sosial seperti jual beli di warung sekitar remaja tersebut tinggal. Pada penelitian ini, peneliti mewawancarai beberapa penjaga warung yang ada di sekitar Desa Jatireja, Kecamatan Cikarang Timur. Kondisi bernegosiasi remaja yang ada di sekitar wilayah tersebut belum bisa dikatakan baik. Hal ini dibuktikan dengan hasil wawancara pada beberapa penjaga warung di sekitar Desa Jatireja. Beberapa narasumber mengatakan bahwa para remaja sering kali menawar dagangan dengan harga yang tidak masuk akal dan juga seringkali mengambil dagangan dan membayar dengan harga yang tidak disepakati oleh penjual. Selain itu, cara bicara remaja saat melakukan proses negosiasi juga tidak baik. Hal tersebut dijelaskan oleh salah satu narasumber yaitu penjaga warung yang ada di samping SMK Informatika Amanah Bangsa. Banyak remaja yang tidak memperhatikan siapa lawan bicara saat melakukan proses negosiasi. Cara bicaranya terdengar tidak sopan kepada orang yang lebih tua.

Buruknya kondisi kemampuan negosiasi remaja berpengaruh pada lingkungan sekolah. Beberapa kegiatan negosiasi yang dilakukan oleh remaja di lingkungan sekolah dijumpai peneliti pada saat adanya kegiatan peneliti di beberapa sekolah, terutama jenjang SMK. Negosiasi yang banyak ditemui peneliti di lingkungan sekolah adalah kegiatan bernegosiasi siswa dengan guru mengenai kegiatan sekolah seperti tenggat waktu pengumpulan tugas-tugas yang telah diberikan oleh guru. Banyak siswa yang gagal bernegosiasi dan akhirnya guru menegur siswanya karena bahasa yang digunakan kurang baik. Biasanya, siswa yang melakukan negosiasi ini adalah siswa yang mempunyai masalah dengan tugas-tugasnya.

Kemampuan menulis teks negosiasi siswa kalangan SMK jauh dari kata baik. Hal ini dapat dilihat saat peneliti melakukan pengamatan langsung ke sekolah. Nilai yang didapat siswa pada tes pembelajaran menulis masih banyak yang di bawah rata-rata sehingga tujuan pembelajaran belum dapat tercapai. Banyak dari siswa tersebut yang sulit menulis karena kesulitan mencari ide yang akan dipaparkan dalam tulisan karena menulis merupakan keterampilan berbahasa yang paling sulit. Menurut Tarigan (2008) menulis merupakan suatu kegiatan yang produktif dan ekspresif. Menurut Susanto (dalam Ni N Ganing 2019 : 285) dinyatakan, keterampilan berbahasa yang dilakukan manusia yang berupa menyimak, berbicara, membaca, dan menulis yang dimodali dengan kosakata, yaitu aktifitas intelektual, karya otak manusia yang berpendidikan.

Negosiasi dapat dilatih dengan cara menulis. Seperti yang tercantum dalam Kurikulum 2013 kelas X semester 2, negosiasi merupakan salah satu materi dari mata pelajaran Bahasa Indonesia. Dalam Kurikukulum 2013, materi teks negosiasi ini memiliki tujuan yaitu siswa dapat terampil menulis teks negosiasi. Menurut Santoso (2018:22) negosiasi adalah kegiatan yang ditimbulkan oleh keinginan memenangkan kepentingan pribadi karena terhambat oleh kepentingan pihak lain dan pemikiran yang bertolak belakang. Dawson (2010:50) mengemukakan bahwa negosiasi dapat dilakukan secara lisan dan tulisan. Berdasarkan teori-teori tersebut,dapat disimpulkan bahwa teks negosiasi adalah teks yang berisi mengenai proses menuju kesepakatan bersama antara dua pihak yang mempunyai perbedaan pendapat atau argumen demi mendapat keuntungan antara satu pihak dan pihak lainnya dan dilakukan secara lisan ataupun tulisan.

Guru sebagai pendidik di sekolah harus memiliki berbagi cara agar tujuan pendidikan dapat tercapai. Berbagai inovasi pembelajaran harus diterapkan agar tujuan dapat tercapai. Zain (2006:2) berpendapat bahwa tujuan pembelajaran dapat tercapai dengan dilakukannya penggunaan metode yang sesuai. Metode yang 
3258 Keefektifan Model Pembelajaran Think Talk Write pada Keterampilan Menulis Teks Negosiasi Siswa SMKHana Awu Putri Utami, Dian Hartati, Roni Nugraha Syafroni

DOI: https://doi.org/10.31004/edukatif.v3i5.1256

diterapkan harus memiliki model pembelajaran. Model pembelajaran di dalam kelas merupakan hal yang terpenting dalam proses belajar mengajar Model pembelajaran sangat beragam bentuknya dan harus dikembangkan agar tujuan pembelajaran dapat tercapai. Menurut Rusman (2018:144) model pembelajaran adalah suatu rencana atau pola yang dapat digunakan untuk membentuk kurikulum (rencana pembelajaran jangka panjang), merancang bahan-bahan pembelajaran, dan membimbing pembelajaran di kelas atau yang lain.

Salah satu bentuk pengembangan model pada pembelajaran menulis teks negosiasi adalah Think Talk Write. Model pembelajaran Think Talk Write diperkenalkan oleh Huinker dan Laughlin. Menurut Huinker dan Laughlin (M.Yasmin \& B.I.Ansari, 2012:84), pada dasarnya model pembelajaran Think Talk Write dibangun melalui berpikir, berbicara, dan menulis. Suatu permasalahan akan dipikirkan baik-baik, kemudian didiskusikan dengan lingkungannya. Think Talk Write adalah model yang memfasilitasi latihan berbahasa secara lisan dan menulis bahasa tersebut dengan lancar (Huda, 2014:218). Berdasarkan beberapa pengertian Think Talk Write menurut beberapa ahli, maka Think Talk Write adalah suatu model pembelajaran yang mengutamakan diskusi atau komunikasi antar peserta didik dan didalamnya terdapat kegiatan berpikir, berbicara dan menulis untuk memecahkan suatu masalah. Alur Think Talk Write dimulai dari aktivitas siswa dalam berpikir atau berdialog dengan dirinya sendiri setelah melakukan kegiatan membaca, selanjutnya berbicara dan memahami ide (sharing) dengan temannya sebelum menulis (Sumayyah, Mustadi, and Harun 2019).Konstruktivisme merupakan teori belajar yang mendasari model pembelajaran. Konstruktivisme adalah salah satu pandangan tentang proses pembelajaran yang menyatakan bahwa dalam proses belajar (perolehan pengetahuan) diawali dengan terjadinya konflik kognitif (Arif Baidowi, Mohammad 2016) Think Talk Write ini adalah pengembangan dari model pembelajaran kooperatif sehingga dapat membantu para siswa untuk berlatih mencari ide dengan berkomunikasi dalam sebuah lingkungan dan langsung mempraktikan pada dunia nyata. Model pembelajaran ini cocok untuk melatih kemampuan menulis karena dapat menjadi alternatif siswa untuk mencari ide yang akan dituangkan kedalam tulisan. Dengan diterapkannya model ini maka peserta didik tidak akan lebih mudah untuk menulis suatu teks.

Artikel berjudul "Pengaruh Model Pembelajaran Kooperatif Tipe Think Talk Write Berbantuan Media Gambar terhadap Keterampilan Menulis Karangan Argumentasi Siswa Kelas X SMA Negeri 5 Padang” dalam Jurnal Pendidikan Bahasa dan Sastra Indoneisa Vol. 5 No. 2 (2016) memaparkan hasil penelitian penerapan model pembelajaran Think Talk Write. Dari artikel tersebut, model pembelajaran Think Talk Write berpengaruh secara signifikan terhadap keterampilan menulis karangan argumentasi. Jadi, disimpulkan bahwa pada penelitian ini keterampilan menulis karangan argumentasi siswa kelas X SMA Negeri 5 Padang sebelum menggunakan model pembelajaran kooperatif tipe Think Talk Write berbantuan media gambar lebih rendah dari pada keterampilan menulis karangan argumentasi siswa kelas X SMA Negeri 5 Padang sesudah menggunakan model pembelajaran kooperatif tipe Think Talk Write berbantuan media gambar.

Artikel yang diteribitkan oleh Wahana Didaktika Jurnal Ilmu Kependidikan Vol. 16 No. 1 (2018) yang berjudul "Pengaruh Model Pembelajaran Think Talk Write (TTW) terhadap Kemampuan Menulis Siswa Kelas XI SMK Setia Darma Palembang" karya Mardiana Sari, dosen Universitas PGRI Palembang menyatakan terdapat pengaruh yang signifikan dari model pembelajaran Think Talk Write (TTW) terhadap hasil belajar menulis karangan argumentasi siswa kelas XI SMK Setia Darma Palembang. Nilai tes awal dan nilai tes akhir dijadikan bahan data untuk dianalisis menggunakan ilmu statistik. Setelah dianalisis, hasil yang diperoleh adalah thitung > ttabel yaitu $1.68<9.04$ dan mengakibatkan Hipotesis nol (Ho) ditolak dan hipotesis alternatif (Ha) diterima.

Berdasarkan alasan yang sudah dijabarkan, maka peneliti dapat memutuskan penelitian yang akan diteliti. Peneliti memutuskan untuk melakukan penelitian "Keefektifan Model Pembelajaran Think Talk Write pada Keterampilan Menulis Teks Negosiasi Siswa Kelas X di SMK Informatika Amanah Bangsa”. Peneliti melakukan penelitian ini dengan cara menerapkan model pembelajaran Think Talk Write kepada siswa kelas X 
3259 Keefektifan Model Pembelajaran Think Talk Write pada Keterampilan Menulis Teks Negosiasi Siswa SMKHana Awu Putri Utami, Dian Hartati, Roni Nugraha Syafroni

DOI: https://doi.org/10.31004/edukatif.v3i5.1256

di SMK Informatika Amanah Bangsa dalam mata pelajaran Bahasa Indonesia materi teks negosiasi. Dengan diterapkannya model pembelajaran ini diharapkan siswa mampu memahami materi dan mengimplementasikannya dalam dunia nyata.

\section{METODE PENELITIAN}

Menurut Abdullah (2015 : 226), populasi adalah kumpulan unit yang akan diteliti ciri-cirinya atau karakteristik dan apabila populasi terlalu luas, maka peneliti harus mengambil sampel (bagian dari populasi) itu untuk diteliti. Populasi dalam penelitian ini sebanyak 76 siswa. Setyosari (dalamNym et al. 2019 : 93) mengatakan bahwa teknik sampel kelompok digunakan apabila populasi atau sampel yang tersedia berupa unit-unit rumpun dalam populasi, contohnya menggunakan kelas atau kelompok, dan tidak mungkin mengambil secara acak setiap individual dari setiap kelas. Sampel yang digunakan adalah sebanyak 50 siswa. Peneltian ini merupakan penelitian kuantitatif dengan metode eksperimen. Menurut A.Ismayani (2019:26) penelitian kuantitatif merupakan sebuah penyelidikan tentang masalah sosial berdasarkan pada pengujian sebuah teori yang terdiri dari variabel-variabel, diukur dengan angka, dan dianalisis dengan prosedur statistik untuk menentukan apakah generalisasi prediktif tersebut benar. Desain yang digunakan adalah Nonequivalent Control Group Design. Menurut Sugiyono (2016 : 76) pada desain ini kelompok eksperimen maupun kelompok kontrol tidak dipilih secara random

\begin{tabular}{|lll|}
\hline $\mathrm{O}_{1}$ & $\mathrm{X}$ & $\mathrm{O}_{2}$ \\
$\mathrm{O}_{3}$ & & $\mathrm{O}_{4}$ \\
\hline
\end{tabular}

Gambar 1. Nonequivalent Control Group Design

$\begin{array}{ll}\text { Keterangan: } \\ \mathrm{X} & \text { : Perlakuan } \\ \mathrm{O} 1 & \text { : Pretest } \text { kelas eksperimen } \\ \mathrm{O} 2 & \text { : Posttest } \text { kelas eksperimen } \\ \mathrm{O} 3 & \text { : Pretest } \text { kelas kontrol } \\ \mathrm{O} 4 & \text { : Posttest } \text { kelas kontrol }\end{array}$

Rancangan atau peneliti dalam penerapan Nonequivalent Control Group Design adalah; (1) Peneliti membagi sampel menjadi kelas kontrol dan kelas eksperimen (2) Peneliti memberikan pretest kepada kelas eksperimen dan kelas kontrol (3) Peneliti memberikan perlakuan kepada kelas eksperimen (4) Peneliti memberikan posttest kepada kelas kontrol dan kelas eksperimen (5) Peneliti menganalisis hasil tes pada kelas kontrol dan kelas eksperimen (6) Membuat kesimpulan.

Analisis data menggunakan analisis uji $t$ independent samples test dan akan diteruskan uji N-Gain untuk menjawab hipotesis yang telah dibuat. Sebelum melakukan uji t dan uji N-Gain, data harus diketahui apakah berdistribusi normal dan homogen atau tidak. Dalam proses analisis, peneliti manggunakan bantuan aplikasi IBM SPSS Statistics 25.

Uji normalitas dilakukan untuk mengetahui apakah sebaran data yang akan diuji normal atau tidak. Normalitas suatu data adalah syarat mutlak dari uji statistik parametrik. Uji normalitas data dapat dihitung dengan uji Kolmogorov Smirnov dengan taraf signifikansi 0,05 (5\%). Data dapat dikatakan normal jika nilai signifikansi hitung > 0,05 (S.Pramesti, 2018:183)

Uji kehomogenan suatu varian dilakukan agar mengetahui apakah data yang akan diuji memiliki varian yang sama atau tidak. Uji homogenitas menggunakan SPPSS dapat dianalisis dengan Levene Test. Dasar pengambilan keputusan dalam tes ini adalah data dikatakan homogen jika nilai probabilitas $>0,05$. Sebaliknya 
3260 Keefektifan Model Pembelajaran Think Talk Write pada Keterampilan Menulis Teks Negosiasi Siswa SMKHana Awu Putri Utami, Dian Hartati, Roni Nugraha Syafroni

DOI: https://doi.org/10.31004/edukatif.v3i5.1256

jika nilai probobilitas < 0,05 maka data dikatakan tidak homogen. (S.Santoso, 2019:86) Uji t dua sampel bebas atau uji t dua sampel tidak berpasangan adalah menguji perbedaan antara kelompok data yang berbeda. Ketentuan pengambilan keputusan berdasarkan nilai probabilitas adalah jika probabilitas $>0,05$ maka $\mathrm{H} 0$ diterima, sebaliknya jika probabiltas < 0,05 maka H0 ditolak (S.Santoso, 2019:88).

$\mathrm{H}_{0}$ : Tidak terdapat perbedaan yang signifikan

$\mathrm{H}_{1}$ : Terdapat perbedaan yang signifikan

Uji N-Gain ini dilakukan Uji N-Gain dilakukan pada masing-masing kelas untuk mengetahui peningkatan pembelajaran pada tiap kelas. Rumus menghitung skor N-Gain adalah sebagai berikut.

$$
\mathrm{N}-\text { Gain }=\frac{\text { Skor Posttest }- \text { Skor Pretest }}{\text { Skor Maksimal }- \text { Skor Pretest }} \times 100
$$

Adapun kategori skor Gain ternolmalisasi dibagi dalam tiga kategori. Berikut tabel kriteria Gain ternormalisasi.

\begin{tabular}{ll}
\multicolumn{2}{c}{ Tabel 1. Klasifikasi Skor N-Gain } \\
\hline \multicolumn{1}{c}{ Presentase } & \multicolumn{1}{c}{ Klasifikasi } \\
\hline N-Gain $>70$ & Tinggi \\
\hline $30 \leq$ N-Gain $\leq 70$ & Sedang \\
\hline N-Gain $<30$ & Rendah \\
\hline
\end{tabular}

\section{HASIL DAN PEMBAHASAN PENELITIAN}

Hasil rata-rata nilai pretest menunjukan bahwa rata-rata nilai pretest kelas kontrol lebih besar daripada rata-rata nilai kelas eksperimen. Kelas kontrol mendapatkan rata-rata nilai pretest sebesar 77,60 sedangkan kelas eksperimen mendapatkan rata-rata nilai sebesar 60,72. Hal ini menunjukan bahwa kemampuan keterampilan menulis teks negosiasi siswa kelas kontrol lebih baik daripada siswa kelas eksperimen.

Setelah kedua kelas diberikan perlakuan yang berbeda, hasil posttest yang didapatkan siswa berubah signifikan. Nilai rata-rata kelas kontrol sebesar 80,40 sedangkan kelas eksperimen sebesar 84,12. Maka, hasil posttest dengan penerapan model pembelajaran Think Talk Write lebih besar daripada model pembelajaran yang biasa diterapkan guru mata pelajaran. Untuk menguji hipotesis yang disusun dengan uji N-Gain, maka perlu dilakukan beberapa proses olah data.

Tabel 2. Uji Normalitas

\begin{tabular}{lcc}
\hline & Kolmogorov-Smirnov & Keterangan \\
\hline Posttest Kontrol & 0,064 & Normal \\
\hline Posttest Eksperimen & 0,066 & Normal \\
\hline
\end{tabular}

Tabel di atas menunjukkan bahwa nilai signifikansi pada posttest kelas kontrol dan kelas eksperimen lebih besar dari 0,05 (sig. > 0,05). Dikarenakan hasil nilai signifikansi pada uji Kolmogorov-Smirnov lebih besar dari 0,05 , maka kedua data dinyatakan normal.

Tabel 3. Uji Homogenitas

\begin{tabular}{ccc}
\hline \multirow{3}{*}{ Posttest } & \multicolumn{2}{c}{ Uji Levene Statistic } \\
\cline { 2 - 3 } & Sig. & Keterangan \\
\cline { 2 - 3 } & 0,132 & Homogen \\
\hline
\end{tabular}


3261 Keefektifan Model Pembelajaran Think Talk Write pada Keterampilan Menulis Teks Negosiasi Siswa SMKHana Awu Putri Utami, Dian Hartati, Roni Nugraha Syafroni

DOI: https://doi.org/10.31004/edukatif.v3i5.1256

Berdasarkan hasil perhitungan uji homogenitas dengan uji Levene Statistic, didapatkan nilai signifikansi sebesar 0,132. Hal ini menyatakan bahwa nilai signifikansi lebih besar dari 0,05 (sig. $>0,05$ ) yang berarti data posttest kemampuan menulis teks negosiasi bersifat homogen atau varian sama.

Tabel 4. Uji Independent Samples Test

\begin{tabular}{|c|c|c|}
\hline \multirow{3}{*}{ Posttest } & \multicolumn{2}{|c|}{$\begin{array}{l}\text { Independent Samples Test } \\
\text { (Equal Variance Assumed) }\end{array}$} \\
\hline & Sig. (2-tailed) & Keterangan \\
\hline & 0,009 & Berbeda signifikan \\
\hline
\end{tabular}

Berdasarkan hasil perhitungan di atas, didapatkan nilai signifikasi sebesar 0,009. Dengan kata lain, nilai signifikansi lebih kecil dari 0,05. Maka dapat disimpulkan bahwa terdapat perbedaan yang signifikan antara nilai posttest kelas kontrol dan kelas eksperimen.

Tabel 5. Uji N-Gain

\begin{tabular}{lll}
\hline \multicolumn{1}{c}{ Kelas } & \multicolumn{1}{c}{ Rata-rata $N$-Gain } & \multicolumn{1}{c}{ Kategori } \\
\hline Kontrol & 0,054 & Sedang \\
\hline Eksperimen & 0,530 & Tinggi \\
\hline
\end{tabular}

Berdasarkan tabel di atas, rata-rata skor N-Gain pada kelas kontrol sebesar 0,054 dengan kategori sedang. Rata-rata skor N-Gain pada kelas eksperimen sebesar 0,530 dengan kategori tinggi. Dengan kata lain, terdapat peningkatan yang tinggi pada hasil belajar dengan penerapan model pembelajaran Think Talk Write. Sementara itu, peningkatan hasil belajar pada model pembelajaran yang biasa dilakukan oleh guru, hanya sedikit mengalami peningkatan.

Dikarenakan terdapat peningkatan hasil belajar dengan diterapkannya model pembelajaran Think Talk Write, model pembelajaran Think Talk Write dapat menjadi alternatif model pembelajaran, terutama pada keterampilan menulis teks negosiasi. Selain itu, dapat berguna memperbaiki kualitas siswa di sekolah, terutama pada keterampilan menulis teks negosiasi.

Hasil penelitian ini sejalan dengan beberapa penelitian yang telah dilakukan. Pada penelitian Devi (2018) menunjukkan bahwa penerapan strategi Think Talk Write (TTW) dapat meningkatkan keterampilan menulis teks ulasan film pendek siswa. Selain itu, penelitian yang dilakukan oleh Afriani and Basri (2016) menyatakan bahwa keterampilan menulis karangan argumentasi siswa kelas X SMA Negeri 8 Padang setelah menggunakan teknik Think Talk Write lebih baik dari sebelumnya menggunakan teknik Think Talk Write.

\section{KESIMPULAN}

Berdasarkan hasil analisis, peningkatan hasil keterampilan menulis menggunakan model pembelajaran Think Talk Write lebih tinggi daripada penerapan model pembelajaran yang biasa diterapkan oleh guru. Maka, model pembelajaran Think Talk Write efektif jika diterapkan dalam pembelajaran menulis teks negosiasi di SMK Informatika Amanah Bangsa.

\section{DAFTAR PUSTAKA}

Afriani, Yelsa, And Irfani Basri. 2016. "Pengaruh Teknik Think Talk Write ( Ttw ) Terhadap Keterampilan Menulis Karangan Argumentasi Siswa Kelas X Sma Negeri 8 Padang,” No. September: 507-13.

Arif Baidowi, Sumarni, Ahmad Amirudin. 2016. "Pengaruh Model Pembelajaran Berbasis Proyek Terhadap 
3262 Keefektifan Model Pembelajaran Think Talk Write pada Keterampilan Menulis Teks Negosiasi Siswa SMKHana Awu Putri Utami, Dian Hartati, Roni Nugraha Syafroni

DOI: https://doi.org/10.31004/edukatif.v3i5.1256

Kemampuan Menulis Karya Ilmiah Geografi Siswa Sma” 3.

Dawson, Roger. 2010. Seni Negosiasi : Seni Canggi Yang Melejitkan Kesuksesan Anda (Secret Of Power Negotiating). Bandung: Gramedia Pustaka Utama.

Devi, Aliza Keumala. 2018. "Peningkatan Kemampuan Menulis Teks Ulasan Film Pendek Pada Siswa Dengan Strategi Think Talk Write." Jurnal Penelitian Pendidikan 18 (2): 109-23. Https://Doi.Org/10.17509/Jpp.V18i2.12952.

Fitri, Yulia, Syahrul R, And Andria Catri Tamsin. 2016. "Pengaruh Model Pembelajaran Kooperatif Tipe Think Talk Write Berbantuan Media Gambar Berseri Terhadap Keterampilan Menulis Teks Cerpen Siswa Kelas VII SMP Negeri 8 Padang." Pendidikan Bahasa Dan Sastra Indonesia 5 (2): 548-55.

Ganing, Ni Nyoman. 2019. "Pengaruh Model Pembelajaran Picture And Picture Berbantuan Media Visual Terhadap Keterampilan Indonesia" 3: 278-85.

Huda, Miftahul. 2014. Model-Model Pengajaran Dan Pembelajaran. Yogyakarta: Pustaka Pelajar.

Ismayani, A. 2019. Metodologi Penelitian. Aceh: Syiah Kuala University Press.

Maru'f Abdullah. 2015. Metode Penelitian Kuantitatif.

Nym, Ni, Chintya Pradnyawathi, Gst Ngr, And Sastra Agustika. 2019. "Pengaruh Model Pakem Berbasis Tri Hita Karana Terhadap Keterampilan Menulis" 3 (1): 89-98.

Rusman. 2018. Model-Model Pembelajaran. Depok: Raja Grafindo Persada.

S.Pramesti. 2018. Mahir Mengolah Data Penelitian Dengan SPSS 25. Jakarta: Kompas Gramedia.

Santoso, A. D. 2018. Diskusi, Negosiasi Dan Ceramah. Surakarta: PT. Aksarra Sinergi Media.

Santoso, S. 2019. Mahir Statistik Parametrik. Jakarta: Kompas Gramedia.

Sari, Dmardiana. 2018. "Pengaruh Model Pembelajaran Think Talk Write (Ttw) Terhadap Kemampuan Menulis Siswa Kelas Xi Smk Setia Darma Palembang." Wahana Didaktika 1: 89-98.

Sugiyono. 2016. Metodologi Penelitian. Bandung: Alfabeta.

Sumayyah, Sumayyah, Ali Mustadi, And Harun Harun. 2019. "Penilaian Aktivitas Siswa Dalam Keterampilan Menulis Melalui Model Think Talk Write." Premiere Educandum: Jurnal Pendidikan Dasar Dan Pembelajaran 9 (1): 23. Https://Doi.Org/10.25273/Pe.V9i1.3966.

Tarigan, H.G. 2008. Menulis Sebagai Suatu Keterampilan Berbahasa. Bndung: Angkasa.

Yamin, M, And B.I Ansari. 2012. Taktik Mengembangkan Kemampuan Individual Siswa. Jakarta: Refrensi.

Zain, D.D. 2006. Strategi Belajar Mengajar. Jakarta: Rineka Cipta. 